country around point to a military or political occupation, rather than one of economic significance. It was, Dr. Wheeler concludes, a military rallying post for the peoples of the surrounding country, the Osismii, at the time of the Roman conquest. This conclusion is supported by the examination of the camp at Le Petit Celland, where the Gallic ramparts were never completed, but were destroyed by military action at a date indicated by coins of local type to coincide in time with Cæsar's campaign.

Interesting as were these discoveries, they had provided the expedition with no analogy with the complex forts of the Wessex Downs ; and its activities accordingly were then directed to southern Brittany. Here on the jagged cliffs, the bays, and wooded estuaries from Douarnenez to the mouth of the Loire, the home of the Veneti, Cæsar's strenuous and troublesome opponents by land and sea, are situated more than three fourths of the fortified works of this period in north-western France. Wherever in this region digging has taken place, multiple ditches and quantities of sling-stones have appeared. "Here, and here only", to quote Dr. Wheeler, "are the true forerunners of those tumultuous defences of SouthWestern Britain, in which the present research originated"; and in the name of the type camp excavated, Kercaradec, he is reminded of the familiar Shropshire Caer Caradoc. Dr. Wheeler goes on to suggest that as a result of the defeat of the Veneti in Cæsar's campaign of 56 B.c., a remnant escaping from Roman vengeance for rebellion may have escaped to settle in Britain, following the earlier rouite already familiar to traders and prospectors who, there is evidence to show, had made their way to Cornwall.

\title{
Forest Types in India and Burma
}

$\mathrm{I}^{\mathrm{x}}$ a prefatory note to his monograph entitled "A Preliminary Survey of Forest Types in India and Burma" (Ind. For. Rec., N.S. 1, No. 1, Govt. Press, Delhi, 1936), Mr. H. G. Champion, sylviculturist at the Dehra Dun Forest Research Institute, defines the purpose of the work. From the point of view of the average forest officer in India, Gamble's 'Manual of Indian Timbers" and Brandis' "Indian Forest Trees" fulfilled ordinary requirements, to which Troup's "Sylviculture of Indian Trees" and Stamp's "Vegetation of Burma" afforded additional information. Mr. Champion's objective was different from that of forest botany pure and simple. As he correctly states, "The need of a standard classification for the important forest types of India has long been felt in connection with sylvicultural work, particularly in its application to forest management under working plans, and this need has led to the adoption of local standard types in some provinces".

In temperate Europe the forest types are comparatively few in number, and for the purposes of the working plans officer easy to define without danger of misapprehension. In the tropical and subtropical forest regions, the position is far more complicated. This problem had come up previously at sylvicultural conference meetings held at Dehra Dun; one of the puzzling undefined types, for example, being the term 'tropical evergreen'. Mr. Champion solicited the assistance of the provincial research sylviculturists, and as a result a certain amount of a variable material was sent in. This, with such information as had been already published, was utilized in conjunction with his own recorded observations made in all parts of India during the preceding twenty years in the compilation of the publication under review.

As the author says, working plans generally include a description of forest types with which they are concerned, and give lists of the characteristie plants of each. In the present reviewer's opinion, working plans should always include a description of the forest types, etc. But it is essential that the forest officer carrying out the provisions of the plan should know exactly the forest type or types to which the working plans officer is alluding. Herein lies the value of Mr. Champion's work. It is by no means to be regarded as complete. "The account of the Peninsular and Burma sub-tropical forest types is outstandingly incomplete", he tells us ; and there are other parts in the monograph where further information is required, and the author adds that criticism of the classification adopted will be welcomed. The work is illustrated by some typical photographs, for the most part taken by past and present forest officers, also by an informative coloured diagrammatic map showing the distribution of climatic types.

The monograph comprises some 286 pages and may be regarded as a valuable aid to the forest officer engaged upon important work in forest management and working plans. A brief résumé only can be attempted here.

A classification of the forest types in India is attempted, based on four elimatic zones from the point of view of temperaturo-tropical, subtropical, temperate and alpine. Each zone is subdivided on available moisture as reflected by the relative importance of evergreen, deciduous and thorny trees. Whilst the form of the tropical forests is similar on both sides of the Tropic of Cancer, the author considers that the flora is sufficiently different to render subdivision into northern (quasi-subtropical) and southern variations advisable. Omitting moist and dry alpine scrub, thirteen formations are distinguished, seven of them subdivided into northern and southern variations.

The six tropical formations are sub-divided into thirty-three forest types, most of which are admittedly composed of several associations, these being indicated where possible; important edaphic variants (twenty-four) are listed and successions are discussed leading to the recognition of twelve primary and ten secondary important seral types. Subtropical and temperate forests are dealt with in a similar fashion. For each type a general description of the forest and the locality factors is given, with plant lists for typical examples, and ecological notes.

The author stresses the lacunæ to be filled up; but in even its present form his monograph should be of considerable use, not only to India but in the forests of the world where similar problems are being faced. 